\title{
Origin of renal cell carcinomas
}

\author{
Manuel Valladares Ayerbes ${ }^{1}$, Guadalupe Aparicio Gallego ${ }^{2}$, Silvia Díaz Prado ${ }^{2,3}$, \\ Paula Jiménez Fonseca ${ }^{4}$, Rosario García Campelo ${ }^{1}$, Luis Miguel Antón Aparicio ${ }^{1,3}$
}

\author{
${ }^{1}$ Medical Oncology Service, CHU Juan Canalejo Materno Infantil Hospital, A Coruña, Spain \\ ${ }^{2}$ Investigation \& Oncology Research Unit, CHU Juan Canalejo, La Coruña, Spain \\ ${ }^{3}$ Department of Medicine, University of La Coruña, La Coruña, Spain \\ ${ }^{4}$ Medical Oncology Service, Central Hospital, Asturias, Spain
}

\begin{abstract}
Cancer is a heritable disorder of somatic cells: environment and heredity are both important in the carcinogenic process. The primal force is the "two hits" of Knudson's hypothesis, which has proved true for many tumours, including renal cell carcinoma. Knudson et al. $[1,2]$ recognised that familial forms of cancer might hold the key to the identification of important regulatory elements known as tumour-suppressor genes. Their observations (i.e., that retinoblastoma tend to be multifocal in familial cases and unifocal in sporadic presentation) led them to propose a two-hit theory of carcinogenesis. Furthermore, Knudson postulated that patients with the familial form of the cancer would be born with one mutant allele and that all cells in that organ or tissue would be at risk, accounting for early onset and the multifocal nature of the disease. In contrast, sporadic tumours would develop only if a mutation occurred in both alleles within the same cell, and, as each event would be expected to occur with low frequency, most tumours would develop late in life and in a unifocal manner [3, 4]. The kidney is affected in a variety of inherited cancer syndromes. For most of them, both the oncogene/tumour-suppressor gene involved and the respective germline mutations have been identified. Each of the inherited syndromes predisposes to distinct types of renal carcinoma. Families with hereditary predisposition to cancer continue to provide a unique opportunity for the identification and characterisation of genes involved in carcinogenesis. A surprising number of genetic syndromes predispose to the development of renal cell carcinoma, and genes associated with five of these syndromes have been already identified: VHL, MET, FH, BHD and HRPT2. Few cancers have as many different types of genetic predisposition as renal cancer, although to date only a small proportion of renal cell cancers can be explained by genetic predisposition.
\end{abstract}

\section{Keywords}

Stem cell; Stem cell markers; Bone marrow stem cells 


\section{Plasticity of kidney cells}

The progression of renal stem cells to carcinogenic events and the associated loss of function remain one of the main challenges in kidney cancer. Both glomerular and tubular epithelial cells regress to primitive/embryonic mesenchymal phenotype in response to injury through the trans/dedifferentiation phenomenon. The phenotypic changes affecting renal cells have been labelled transdifferentiation. The term "trans-differentiation" is probably misleading, as it refers to the transformation of one mature, epithelial phenotype into another. The phenotypic changes observed, involving mesangial and epithelial cells, are more likely to represent a step of injury-induced dedifferentiation/regression of these cells into a mesenchymal, embryonic phenotype reminiscent of the metanephric phenotype from which they originate [5]. On the other hand, these events have been described as epithelial mesenchymal transition.

This reverse embryogenesis can be a key step in renal carcinogenesis. In fact, the response to injury of differentiated renal cells is, in some ways, a form of reverse embryogenesis (dedifferentiation) followed by a recapitulated embryogenesis (re-differentiation) leading to the restoration of kidney cell maturity. In addition to the plasticity of intrinsic renal cells, it is becoming apparent that renal remodelling in health and disease involves the migration of progenitor haematopoietic stem cells into the kidneys. These cells assume various glomerular and tubular epithelial phenotypes.

Special mention focuses on the prospective contributions to the renal healing deviation of resident renal cells and those derived from the bone marrow and their circulating progeny.

\section{Plasticity of glomerular cells}

\section{Endothelial cells}

Experimental data suggest that the response of glomerular cells to injury is more complex, involving considerable phenotypic adaptation. For instance, endothelial cells, once injured transiently, lose their mature functional phenotype (i.e., anticoagulant, anti-inflammatory, antiproliferative) and acquire new immature (i.e., procoagulant, proinflammatory and mitogenic) characteristics [6].

\section{Mesangial cells}

The phenotypic changes of mesangial cells in response to injury have been demonstrated. Mesangial cells trans- or de-differentiate in response to injury, from a mature, adult, pericyte-like phenotype (the mesangiocyte) to an embryonic myofibroblastic one (the mesangioblast), characterised by proliferation and contraction $[7,8]$. The appearance of mesangioblasts within glomeruli undergoing repair appears to re-enact the embryonic steps of glomerulogenesis [9-11]. To sum up, the trans/de-differentiation of adult mesangial cells (mesangiocytes) to embryonic mesangioblasts is characteristic of mesangial response to injury.

\section{Epithelial cells}

Glomerular parietal epithelial cells also respond to injury by trans/de-differentiation into a mesenchymal-embryonic phenotype, which is associated with the loss of tubulo-epithelial markers [12]. At the early and later stages of glomerular epithelial-mesenchymal trans-differentiation, epithelial cells retain their morphology [13]. 


\section{Plasticity of tubulointerstitial cells}

Tubular epithelial cells have the capacity to regress from an adult, mature phenotype to an embryonic/mesenchymal one in response to injurious stimuli. This so-called epithelial-mesenchymal trans-differentiation, or rather, transformation, has been reported in response to a variety of stimuli and appears to be mediated by the release of a variety of growth factors (TGF- $\beta 1$, EGF) and cytokines (IL-1) in vitro and in vivo, where the proximal tubular epithelial cells lose their adult phenotype and markers and acquire mesenchymal ones [13-15].

Epithelial-mesenchymal transition is associated with the loss of epithelial phenotype involving cell hypertrophy [14]. This so-called epithelial-mesenchymal transition is merely the regression of the adult phenotype to the tubular epithelial cell's embryonic/metanephric mesenchymal one in response to injury. As the great majority of tubular epithelial cells, including proximal tubular cells, are derived from the same metanephric mesenchyme, these cells can regress to such an embryonic mesenchymal phenotype in response to activation.

\section{The contribution of haematopoietic stem cells}

Bone marrow has multiple types of stem cells (Fig. 1) (haematopoietic stem cells, mesenchymal stem cells, multipotent adult progenitor cells, side population cells) and numerous studies have reported differentiation when these cells engraft in other organ systems.

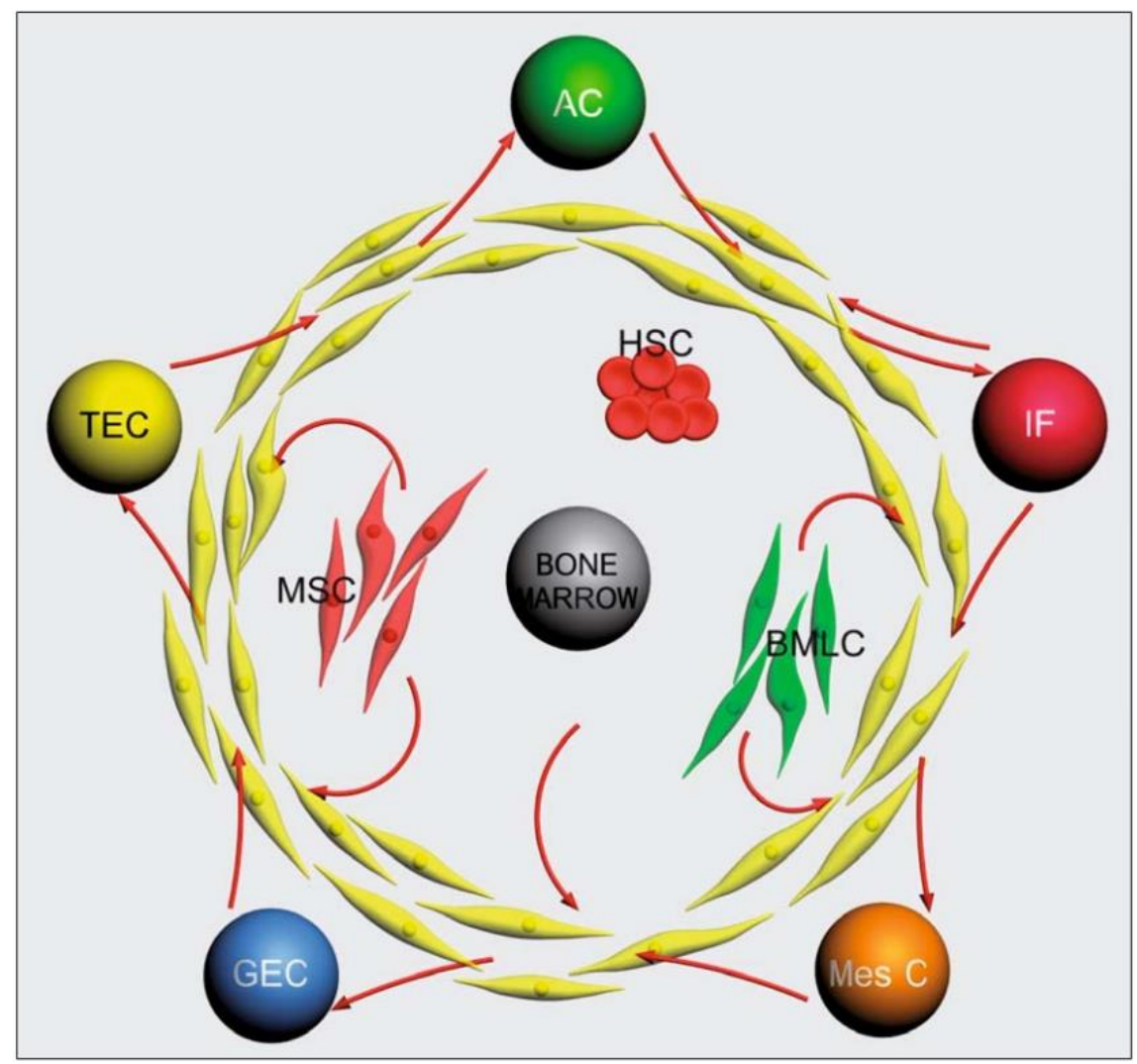

Fig. 1. Theoretical work of bone marrow. Bone marrow stem cells derive into three major populations: MSC, HSC and BMLC. These three populations could give rise to an intermediate stage, $\mathrm{MC} /$ fibroblast. Finally, MC/fibroblast could trans-differentiate to AC, IF, Mes C, GEC and TEC. Abbreviations: MSC, marrow stromal cell; HSC, hematopoietic stem cell; BMLC, bone marrow lining cell; MC, mesenchymal cell; AC, adventitial cell (pericyte); TEC, tubuloepithelial cell (proximal tubules cell); IF, interstitial renal fibroblast; MesC, mesangial cell; GEC, glomerular epithelial cell 
The pluripotency of haematopoietic stem cells is evidenced by their capacity to differentiate into multiple lineages within the blood and immune system, as well as non-cross lineage boundaries to become cells of other tissues, which has challenged the traditional view that somatic stem cells are lineage-restricted and organ-specific. One possibility is that some haematopoietic stem cells retain developmental plasticity and can be programmed to express genes that are required to differentiate into the cells of the organs into which they are introduced.

Bone marrow has received increasing attention during recent years from researchers hoping to reveal a universal stem cell. There are two main reasons for this. Firstly, bone marrow has the capacity for pluripotent differentiation. And secondly, for an organ system in which a native stemcell region has not yet been identified, such as the kidney, bone marrow may serve as an alternative source. Previous discoveries of blood-borne cells in the kidney, and the characterisation of a potential universal stem cell source, giving rise to intact kidney tissue, are challenging long- held views about the nature of the kidney epithelium and its power to renew.

The ability of haematopoietic stem cells to adopt the cell fate of the organs in which they reside suggests that these primitive cells could potentially differentiate into kidney cells during kidney regeneration (Fig. 2). There are reports that provide evidence showing that adult bone-marrowderived haematopoietic stem cells integrate into injured kidneys and differentiate into many renal cells. It has been shown, in experimental models, that bone marrow-derived stem cells can engraft in the kidney and differentiate into mature tubular epithelium, glomeruli and mesangium. Furthermore, resident kidney cells with features of marrow stem cell properties have been identified.

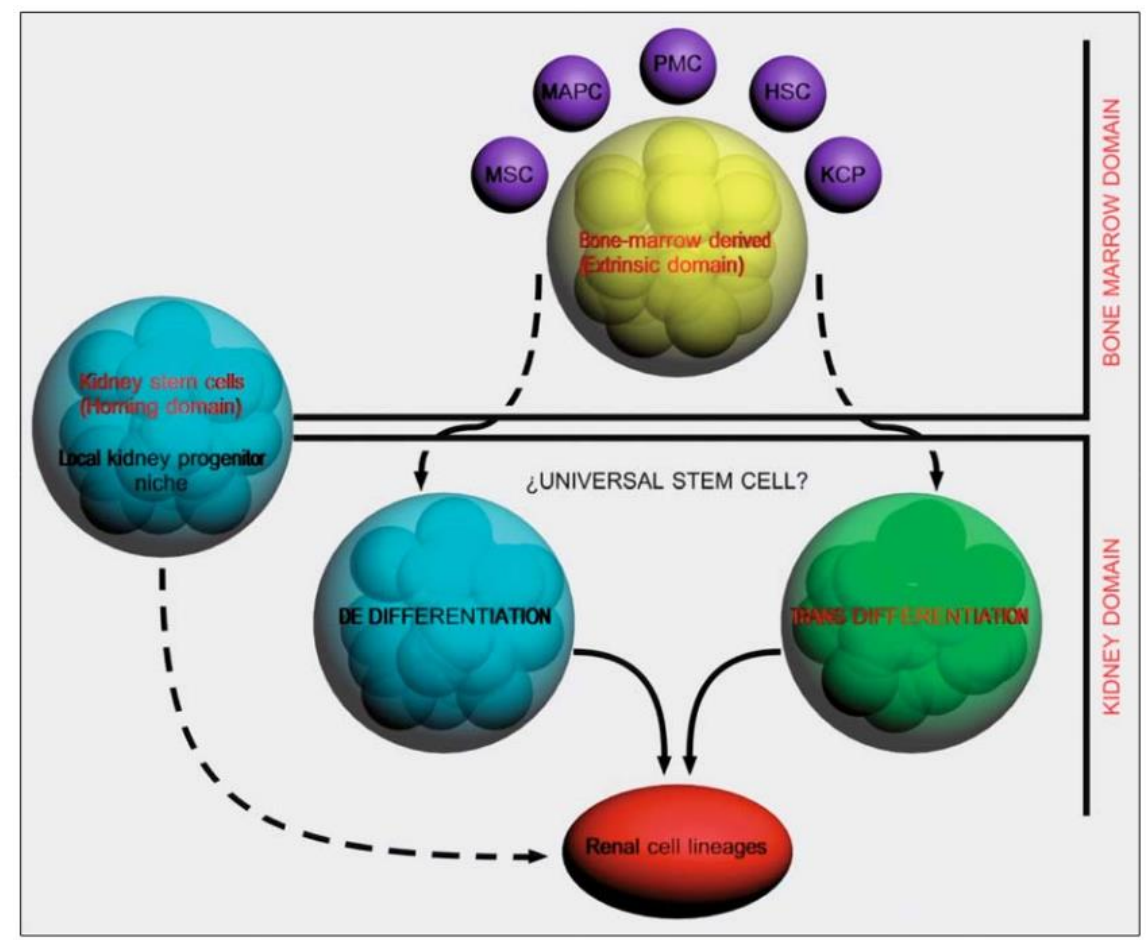

Fig. 2. Plasticity of hematopoietic stem cells. Model of the possible biological explanations for mediate kidney epithelial engrafment. These include: a) trafficking of marrow cells to a local progenitor niche in the kidney, b) fusion of bone marrowderived cells with differentiated epithelial cells in the kidney, and c) direct "transdifferentiation" into kidney epithelial cells. PMC, pluripotent marrow cell; HSC, hematopoietic stem cell; MSC, mesenchymal stem cell; MAPC, multipotent adult progenitor cell; KCP; kidney-committed progenitor 


\section{Hereditary forms of renal carcinoma}

Renal cancer, like other human tumours (i.e., breast, colon and prostate cancers), occurs in a sporadic non-inherited form as well as an inherited or hereditary form (Table 1) [16]. Because there are a number of histological types of renal carcinoma, there are a number of hereditary types of renal carcinoma. Each type of hereditary renal carcinoma is associated with a specific histological type: (1) Von Hippel-Lindau (VHL) is a hereditary form of clear cell renal carcinoma; (2) hereditary papillary renal carcinoma (HPRC) is a hereditary form of papillary renal carcinoma (papillary type I); (3) Birt Hogg Dubé (BHD) is a hereditary form of chromophobe renal carcinoma and oncocytoma; or (4) human leiomyomatosis renal cell carcinoma (HLRCC) is a hereditary form of papillary renal carcinoma (papillary type 2) (Fig. 3).

Table 1. Heritable syndromes associated with kidney neoplasias

\begin{tabular}{|c|c|c|c|}
\hline Syndrome & Causative gene & Renal manifestation & $\begin{array}{l}\text { Other manifestations (benign/malignant) } \\
\text { location }\end{array}$ \\
\hline Von Hippel-Lindau & $\begin{array}{l}\text { (VHL) VHL, } \\
3 \mathrm{p} 25\end{array}$ & $\begin{array}{l}\text { Clear-cell RCC } \\
\text { Solid/Cystic } \\
\text { Multiple/Bilateral }\end{array}$ & $\begin{array}{l}\text { Retinal \& CSN haemangioblastomas } \\
\text { Pheochromocytomas. Neuroendocrine tumor } \\
\text { Pancreatic cysts } \\
\text { Endolymphatic-sac tumors } \\
\text { Epididymal \& broad-ligament cystadenomas }\end{array}$ \\
\hline $\begin{array}{l}\text { Hereditary papillary } \\
\text { Renal carcinoma (HPRC) }\end{array}$ & MET, 7q31 & $\begin{array}{l}\text { Papillary RCC type } 1 \\
\text { Solid/Multiple/Bilateral }\end{array}$ & None? \\
\hline $\begin{array}{l}\text { Hereditary leiomyomatosis } \\
\text { Renal carcinoma (HLRCC) }\end{array}$ & $\mathrm{FH}, 1 \mathrm{q} 42-43$ & $\begin{array}{l}\text { Papillary RCC type } 2 \\
\text { Collecting duct } \\
\text { carcinoma } \\
\text { Solid/Aggressive }\end{array}$ & $\begin{array}{l}\text { Uterine leiomyoma \& leiomyosarcomas } \\
\text { Cutaneous nodules (leiomyomas) }\end{array}$ \\
\hline Birt Hogg Dubé (BHD) & BHD, 17p11.2 & $\begin{array}{l}\text { Chromophobe RCC } \\
\text { Hybrid oncocytoma RCC } \\
\text { Oncocytoma } \\
\text { Clear-cell RCC } \\
\text { Multiple/Bilateral }\end{array}$ & $\begin{array}{l}\text { Cutaneous papules (fibrofolliculomas) } \\
\text { Lung cysts. Spontaneous pneumothorax } \\
\text { Possibly colon polyps }\end{array}$ \\
\hline Hyperparathyroidism-jaw & HRPT2, 1q25-32 & $\begin{array}{l}\text { Mixed epithelial \& } \\
\text { stromal tumors }\end{array}$ & Parathyroid tumor \\
\hline Tumor (HP-JT) & & $\begin{array}{l}\text { Papillary RCC } \\
\text { Cysts }\end{array}$ & $\begin{array}{l}\text { Fibro-osseous mandibular \& maxyllary } \\
\text { tumours }\end{array}$ \\
\hline $\begin{array}{l}\text { Constitutioned } \\
\text { chromosome- } 3 \\
\text { Translocation }\end{array}$ & $\begin{array}{l}\text { Unknown gene } \\
\text { VHL? }\end{array}$ & $\begin{array}{l}\text { Clear-cell RCC } \\
\text { Multiple/Bilateral }\end{array}$ & None? \\
\hline $\begin{array}{l}\text { Familial papillary thyroid } \\
\text { Cancer (FPTC) }\end{array}$ & $\begin{array}{l}\text { Unknown gene } \\
1 \mathrm{q} 21\end{array}$ & $\begin{array}{l}\text { Papillary RCC } \\
\text { Oncocytoma }\end{array}$ & $\begin{array}{l}\text { Papillary thyroid cancer } \\
\text { Nodular thyroid disease }\end{array}$ \\
\hline
\end{tabular}




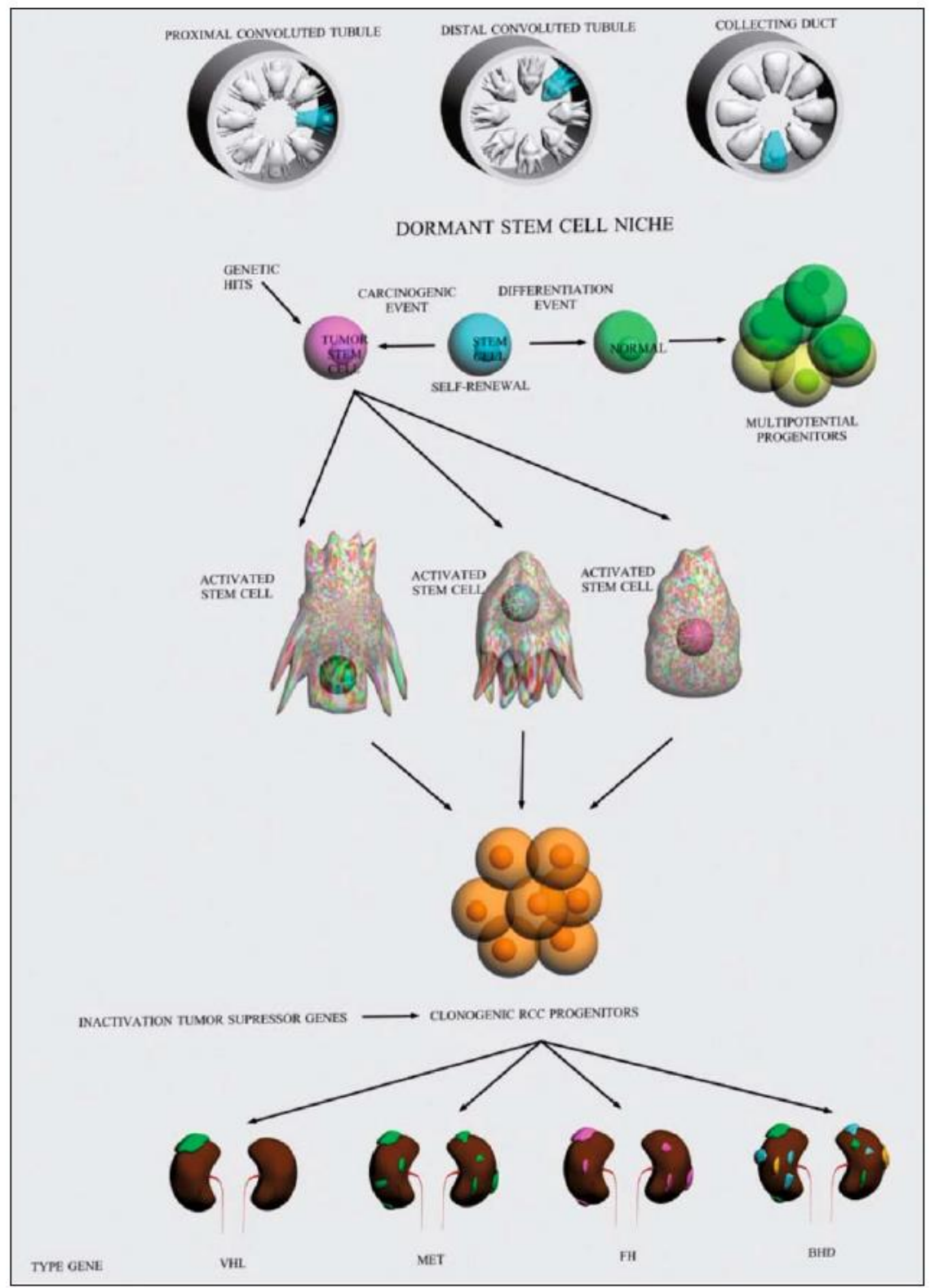

Fig. 3. Kidney cancer is not a single cancer. There are different types of cancer that occur in kidney. These different types of kidney cancer are caused by different genes, they have diverse clinical courses and may respond differently to therapy

Kidney cancer can occur in sporadic as well as hereditary forms. Sporadic kidney cancer tends to occur as a single lesion; inherited forms of kidney cancer can be bilateral and multifocal. The hallmarks of familial renal cancer are that they occur at an early age, and are usually bilateral and multifocal. The type about which most studies are available is associated with VHL disease, in which $40-45 \%$ of affected individuals have clear cell carcinoma [17, 18]. Clear cell renal cancer is also inherited in about $50 \%$ of patients $[19,20]$ with the germline translocations. HPRC is a form of familial cancer that also has autosomal dominant trans- mission but reduced penetrance compared to VHL and familial cell cancer [21, 22]. Hereditary renal oncocytoma is a form of inherited renal tumour [23]. 
Patients with VHL disease, caused by a germline mutation in the VHL gene (chromosome 3p25), have conventional renal cancer as part of an inherited tumour syndrome [24, 25]. Families with a rare hereditary form of conventional renal cancer have germline translocations involving chromosomes 3 , $\mathrm{t}(3 ; 8), \mathrm{t}(3 ; 6)$ and $\mathrm{t}(3 ; 2)[26,27]$. The VHL kidney cancer gene is a tumour-suppressor gene. In VHL tumours the inherited (germline) copy of VHL is mutated, and the second copy of VHL gene is also inactivated, most often by deletion of the gene (Fig. 4). VHL mutations result in carcinogenesis. Tumorigenesis may be related, at least in part, to biochemical processes dependent on inter- action with transcriptional factor proteins referred to as hypoxia-inducible factors (HIF) $1 \alpha$ and $2 \alpha$. HIF $1 \alpha$ and HIF $2 \alpha$ are key proteins involved in oxygen sensation. As a result, HIF1 $\alpha$ and HIF $2 \alpha$ are able to activate the transcription of a variety of genes that may be important for carcinogenesis, including: vascular endothelial growth factor (VEGF), platelet-derived growth factor (PDGF), transforming growth factor $\alpha(\mathrm{TGF} \alpha)$, glucose transporter-1 (Glut-1) and erythropoietin (EPO).

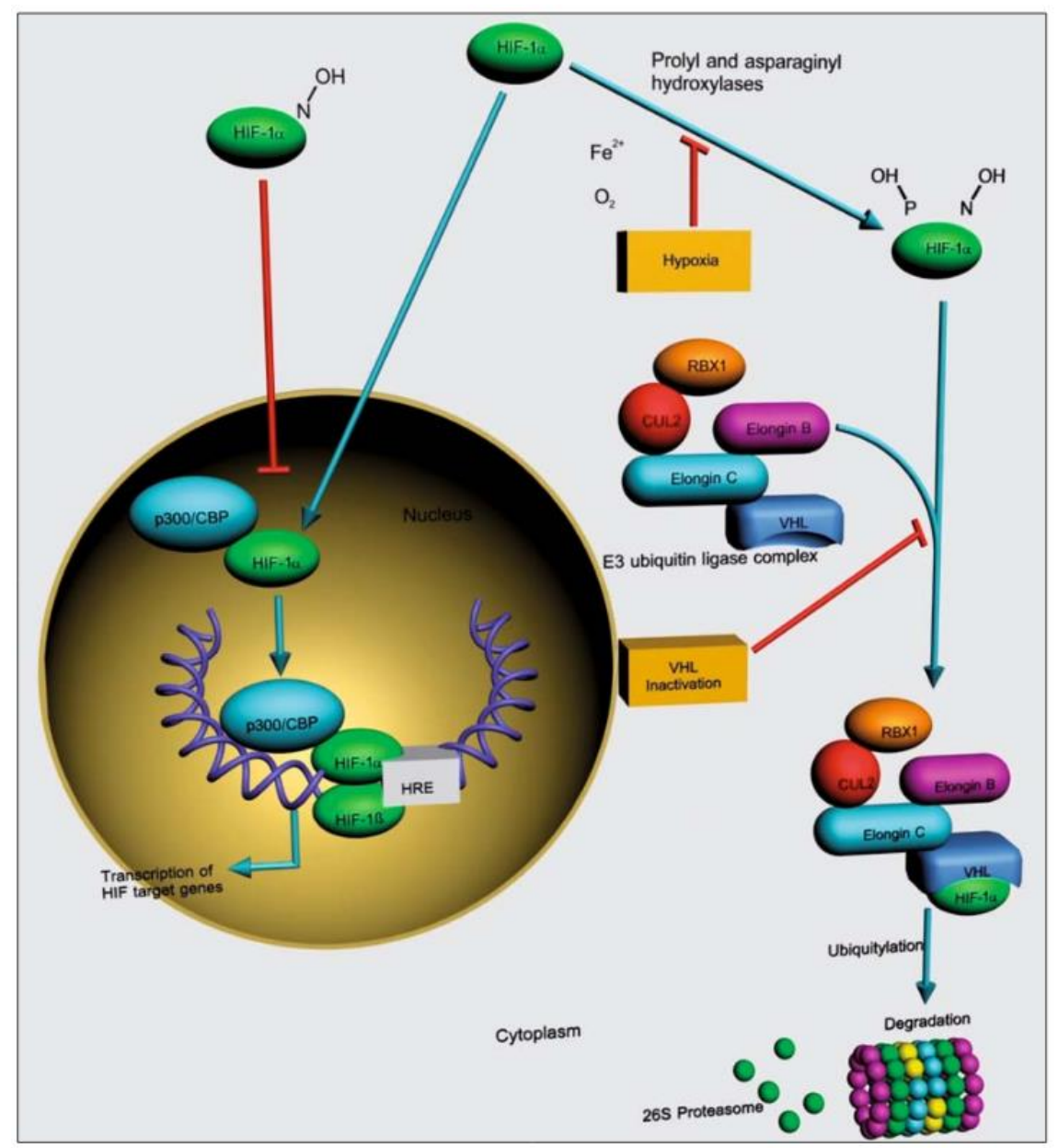

Fig. 4. VHL mutations and kidney carcinogenesis. Tumorigenesis may be related, at least in part, to biochemical processes dependent on interaction with transcriptional factor proteins referred to as hypoxia-inducible factors (HIF) $1 \alpha$ and $2 \alpha$. HIF1 $\alpha$ and HIF2 $\alpha$ are key proteins involved in oxygen sensation 


\section{Hereditary papillary renal carcinoma type 1}

The hereditary papillary renal cell carcinoma gene is the protooncogene c-MET, which was found to be located at chromosome 7q31.1-34 (Fig. 4). Missense mutations were found in the tyrosine kinase domain of the MET gene in the germline of affected members of HPRC kindreds [28]. Mutations in the MET genes were also found to be located in codons that were homologous to those in the c-kit and RET oncogenes. The findings suggested that the missense mutations located in the MET proto-oncogene lead to constitutive activation of the MET protein in papillary renal carcinomas (Fig. 5). c-MET codes for the cell surface receptor for hepatocyte growth factor (HGF). Activation of c- MET by its ligand, HGF, activates the tyrosine kinase activity of c-MET that initiates multiple signal transduction cascades, resulting in cellular processes, including mitogenesis, migration and morphogenesis, which may be carcinogenic when unregulated.

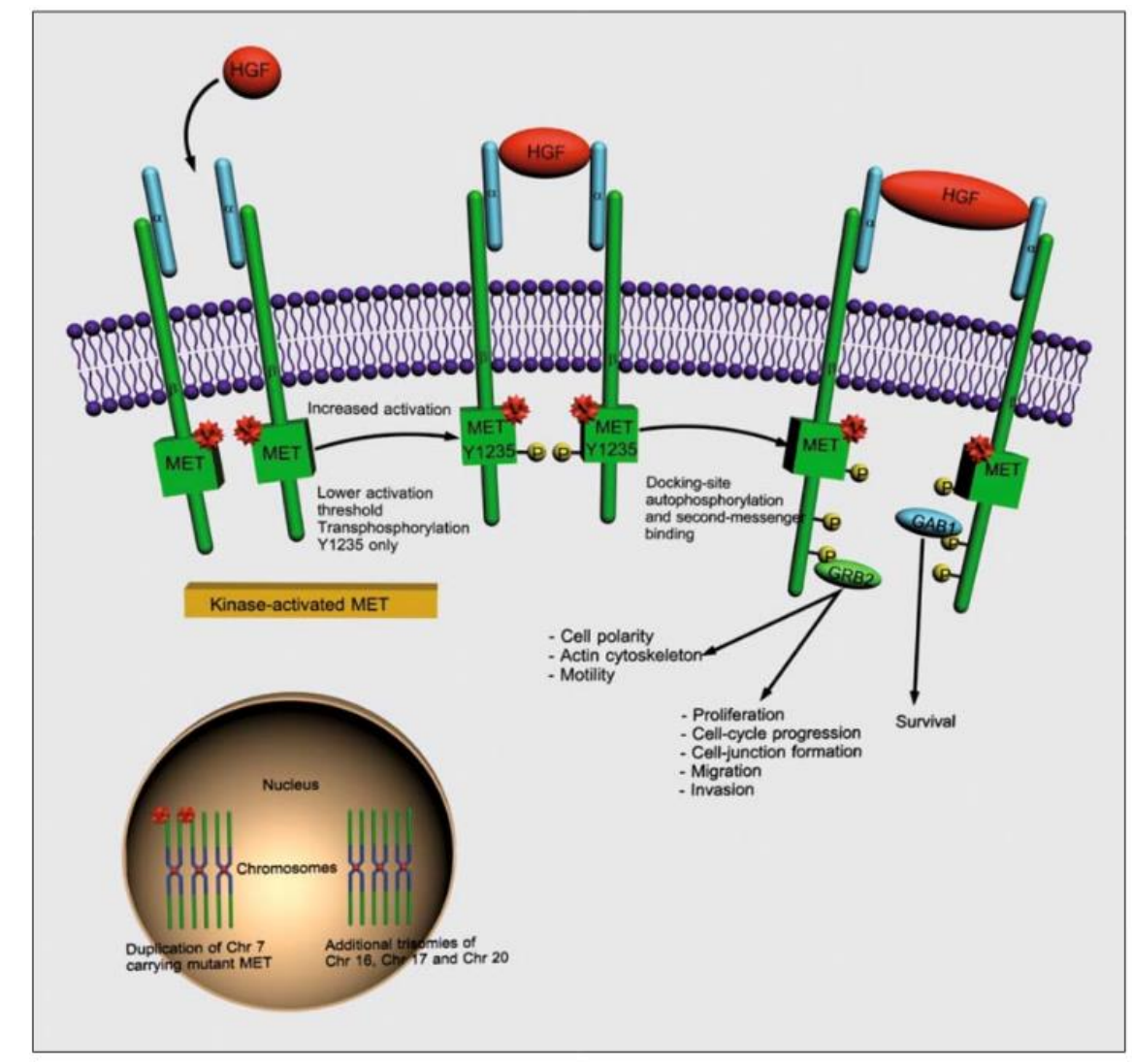

Fig. 5. HPRC cell with Met mutation. Met is a cell surface receptor for ligand HGF. Met gene mutation in germline of affected individuals with HPRC is associated with bilateral, multifocal type 1 papillary renal carcinoma

\section{Hereditary chromophobeloncocytoma: BHD syndrome}

Kidney cancer may develop in 15-30\% of affected BHD cases. The cancers are often bilateral and multifocal, and the most common types of histological types of renal tumour in this syndrome are chromophobe renal carcinoma (34\%), oncocytic-transition neoplasms (50\%) and oncocytoma (5\%). Genetic linkage analysis was performed and the BHD gene was localised on the short arm of chromosome 17 [29]. Mutations of the BHD gene were found in the germline of affected individuals with this syndrome. This gene has characteristics consistent with a tumour-sup- pressor gene [30]. BHD represents a genetic syndrome not linked to the VHL or c-MET genes. 
HLRCC is a hereditary form of papillary renal carcinoma type 2 and represents a disease complex characterised by the appearance of multiple tumours [31,32]. The gene for HLRCC was found to be the gene that codes for fumarate hydratase (FH), a Krebs cycle enzyme (Fig. 6). FH catalyses the hydration of fumarate to form malate. $\mathrm{FH}$ acts as a tumour-suppressor gene, but the exact mechanism for tumorigenesis in HLRC remains to be elucidated. It is known that fumarate, which may accumulate in the setting of depressed FH activity, can prevent HIF hydroxylation by inhibiting prolyl hydroxylase. In the setting of loss of FH activity, fumarate accumulation may cause HIF overexpression and thereby result in a cellular milieu conducive to tumour formation.

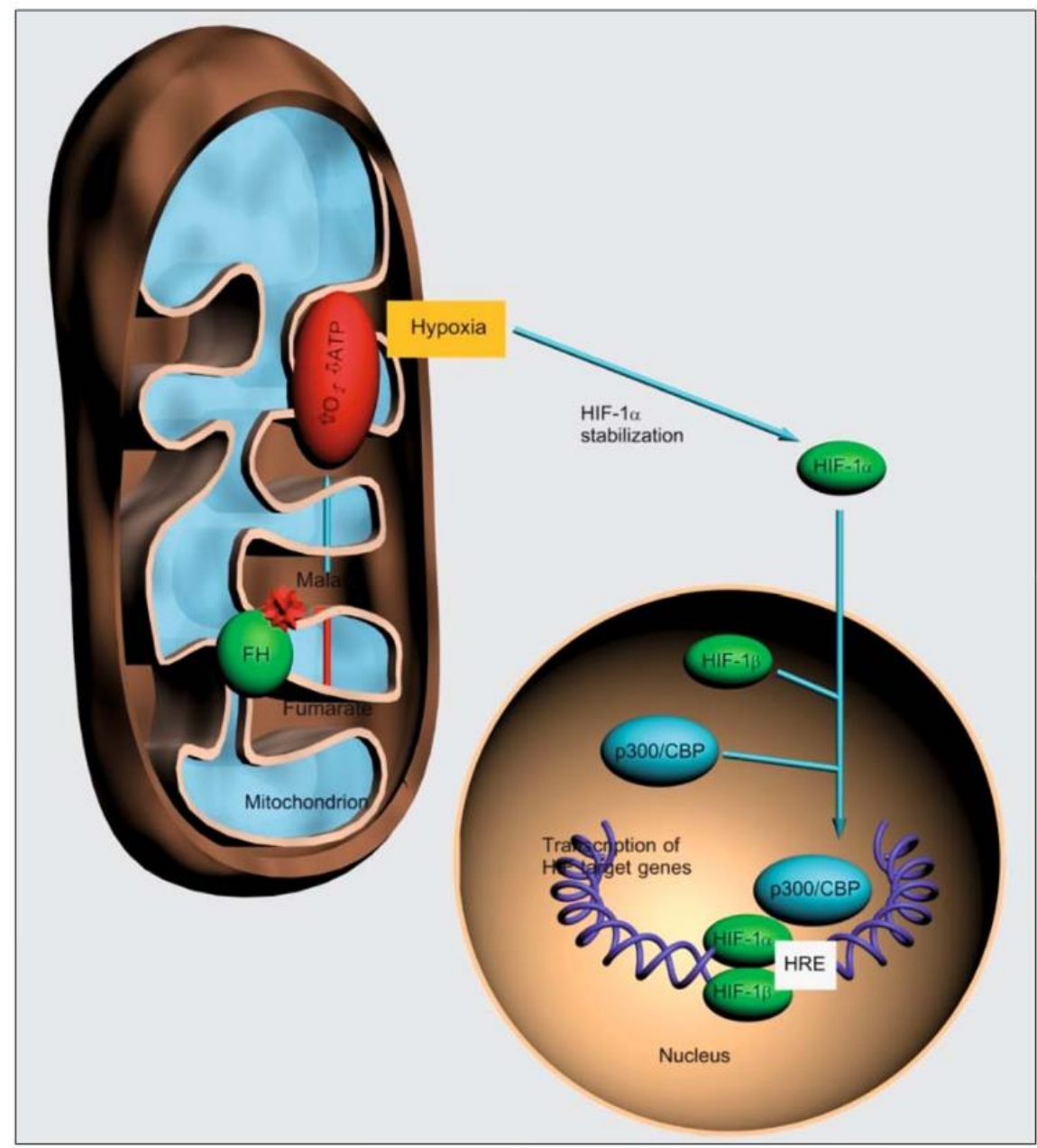

Fig. 6. Fumarate hydratase pathway implicated in human leiomyomatosis renal cell carcinoma 


\section{Genetics of renal neoplasms}

\section{Clear cell carcinoma}

Clear cell carcinoma occurs in both familial and sporadic forms, and in both forms it is characterised by the loss of VHL tumour-suppressor gene. The familial form of the common clear cell variant of renal cell carcinoma is VHL disease. This relatively rare disease is estimated to affect approximately 1 in every 36,000 individuals and is inherited in an autosomal dominant fashion with estimated penetrance of $80-90 \%$ by the age of $65[33,34]$. Renal cell carcinoma eventually develops in approximately 35-45\% of those individuals affected with VHL disease [35]. Early clues to the genetic elements involved in the development of renal cell carcinoma came to form cytogenetics. These studies demonstrated a common loss of chromosome 3 in kidney cancer, particularly the clear variants, and led to intensive efforts to find a tumour-suppressor gene in this region. Southern blot testing and analysis for restriction fragment length polymorphisms with a wide variety of genetic markers subsequently demonstrated loss of heterozygosity in distinct regions on the short arm of chromosome 3 [36]. Molecular linkage studies in patients with VHL disease eventually led to the identification of the VHL tumour-suppressor gene [37]. The VHL gene has been localised to the short arm of chromosome 3, sub-band 25 (3p25) (Table 2) [38-40], and its role as a tumour-suppressor gene for both the sporadic and the familial forms of clear cell renal carcinoma has been confirmed. VHL was linked to the locus encoding the human homologue of the RAF1 oncogene map- ping to the 3p25 chromosome [41] and also linkage to D3S18 (a polymorphic DNA marker) [41] and tight linkage to D3S601 (DNA probe), which was located in the region between RAF1 and D3S18 [42].

Table 2. Classification schema for kidney epithelial neoplasias

\begin{tabular}{|c|c|c|c|}
\hline Histological type & Cell origin & Genes implicated & Chromosomal abnormalities \\
\hline Clear cell RCC & Proximal tubule & VHL, BHD & $\begin{array}{l}-3 p,+5 q,-Y,-9 p,-14 q \\
t(3 ; 5)(p ; q)\end{array}$ \\
\hline Papillary RCC & Proximal tubule & MET, FH, HRPT2 & $\begin{array}{l}+7,+17,-Y,+12,+16,+20 \\
\mathrm{t}(\mathrm{X} ; 1)(\mathrm{p} 11.2 ; \mathrm{q} 21.2) \\
\mathrm{t}(\mathrm{X} ; 17)(\mathrm{p} 11.2 ; \mathrm{q} 25.3)\end{array}$ \\
\hline Chromophobe RCC & $\begin{array}{l}\text { Intercalated cell } \\
\text { Cortical collecting duct }\end{array}$ & BHD & $-1,-2,-6,-10,-13,-17,-21$ \\
\hline Oncocytoma & $\begin{array}{l}\text { Intercalated cell } \\
\text { Cortical collecting duct }\end{array}$ & BHD & $\begin{array}{l}-1,-Y \\
\mathrm{t}(5 ; 11)(\mathrm{q} 35 ; \mathrm{q} 13) \\
\mathrm{t}(9 ; 11)(\mathrm{p} 23 ; \mathrm{q} 13)\end{array}$ \\
\hline Bellini's duct & Medullary collecting duct & $\mathrm{FH}$ & $-7 q 32,-6 p,-8 p,-21 q$ \\
\hline
\end{tabular}

Several hundred germline mutations have now been recognised; these include microdeletions, insertions, large deletions and missense and nonsense mutations. There are mutations identified throughout the coding region, but clustering occurred at the 3 ' end of EXON 1 and the 5' end of EXON 3 with a paucity of mutations in EXON 2. The importance of this is that a specific mutation has now been correlated with certain phenotypic characteristics in VHL patients [43, 44].

An additional genetic abnormality is that chromosomes 3 are often reported in clear cell carcinoma (Table 3). 
Table 3. Additional genetics abnormalities in clear cell carcinoma

\begin{tabular}{|c|c|c|c|c|}
\hline \multirow{2}{*}{$\begin{array}{l}\text { Others chromosome } \\
\text { LOH discrete regions }\end{array}$} & \multicolumn{2}{|l|}{$3 p$ abnormalities } & \multicolumn{2}{|c|}{ HISTOLOGICAL \& CLINICAL FEATURES } \\
\hline & 3p13-p14.2 & & & $(63,64)$ \\
\hline \multicolumn{5}{|l|}{ Early genetic changes } \\
\hline LOH VHL gene & $\begin{array}{l}\text { TGFa/TGF-b1 } \\
\text { c-myc }\end{array}$ & & $\begin{array}{l}\text { dedifferentiation } \\
\text { cellular control } \\
\text { transformation }\end{array}$ & $\begin{array}{l}(65) \\
(66) \\
(67)\end{array}$ \\
\hline \multicolumn{5}{|l|}{ Late events } \\
\hline Duplication & 5q22-qter segment & & progression & $(68,69)$ \\
\hline Trisomy & $5 \mathrm{q}$ & & progression & (70) \\
\hline Mutation & 17 p13 high mutation & p53 & sarcomatous profile & $(71,72)$ \\
\hline & Low mutation & p53 & carcinomatous profile & $(73,74)$ \\
\hline LOH 17p & & & $\begin{array}{l}\text { tumor grade } \\
\text { nodal metastases }\end{array}$ & $\begin{array}{l}(75,76) \\
(77)\end{array}$ \\
\hline Allelic loss & $17 p 8 p 9 p 11 p$ & & & \\
\hline & $14 q 13 q$ & & tumor progression & $(78,79)$ \\
\hline Hepatocyte growth factor & & & overexpression & $(80-82)$ \\
\hline c-erbB-1 oncogene & & & overexpression & (83) \\
\hline HER 2/neu oncogene & & & low expression & (84) \\
\hline
\end{tabular}

\section{Papillary renal cell carcinoma}

There are two broad classifications of the tumour: sporadic and hereditary. The main cytogenetics abnormalities associated with chromophilic renal cell carcinoma are characteristic (Table 2) and include trisomy of chromosomes 7 and 17 and loss of the Y chromosome. Other common findings include gain of chromosomes 12, 16 and 20 and loss of heterozygosity on chromosome 14. Papillary renal cell carcinoma has not been associated with $3 p$ mutations (as is found in clear cell carcinoma), confirming distinct genetic pathways to tumorigenesis. Instead, it is associated with the MET protooncogene, found on chromosome 7 [45], which encodes the receptor for HGF [46]. This gene was localised to chromosome 7q31-34 and activation of the MET proto-oncogene is the inciting event, rather than inactivation of a tumour-suppressor gene. Oncogenic properties of the MET gene are related with amplifications and mutations that result in the activation of this encoded protein [47, 48]. The protein product of this gene is the receptor tyrosine kinase for the HGF (also known as "scatter factor"), which plays an important role in the normal organogenesis, proliferation and differentiation of epithelial and endothelial cells in a wide variety of organs, including the kidney.

Sporadic papillary carcinoma of the kidney is associated with more than one chromosomal abnormality: $80 \%$ possess polysomies [49]; 80-90\% have been associated with loss of their Y chromosome [50]; loss of heterozygosity is detected on chromosomes 9q, 11q, 14q, 21q and 6p [51]; somatic translocations of chromosomes 1 and $X$ have been reported [52]. To sum up, the most common trisomies that have been observed include trisomy of chromosomes 7, 17 and 16 [46, 49, 53].

Hereditary papillary renal cell carcinoma is associated with abnormalities of chromosome 7 [54], especially the MET proto-oncogene [55]. The MET proto-oncogene has been localised to the 7q31.3 region [56]. Trisomy for chromosome 7 , which is commonly found in hereditary papillary renal cell carcinoma, develops primarily through du-plication of the chromosome harbouring the mutant allele of the MET proto-oncogene and increases the dosage of the activated receptor, and this non-random event also con- tributes to the development of the tumour diathesis [57]. The second type of hereditary papillary renal cell carcinoma (referred to as type 2) is an autosomal-dominant condition due to a mutation in the $\mathrm{FH}$ gene [56]. The FH gene maps to the 1q42.3-43 chromosome. It is believed that FH is an enzyme of the Krebs cycle and is a "housekeeping" gene. 
Genetic analysis [57] has revealed loss of heterozygosity at chromosomes 1, 6, 10, 13, 17 and 21 (Table 2); in most cases there is demonstrated hypodiploid DNA content [58].

Chromophobic renal cell carcinoma is commonly seen in BHD syndrome [59], but is rare in sporadic renal tumours [57]. The BHD gene has been mapped to the 17p11.2 locus (Fig. 4) and is thought to be a tumour-suppressor gene [60]. Some studies have reported an increased incidence of p53 mutation in this histologic subtype, and upregulated expression of the c-kit oncogene has also been reported [61].

\section{Collecting duct (Bellini's duct)}

Deletions on chromosome 1q (loss of heterozygosity at 1q32.1-32.2) and monosomies of chromosomes 6, 8, 11, 18,21 and Y are reported [40] (Table 2).

Collecting duct carcinomas are typically characterised by hypodiploid stem lines with chromosomes 1, X and Y most commonly affected [44]. Additional abnormalities have been found on chromosomes 22 and 23 [62].

\section{Pathological features}

Kidney cancer is not a single disease, but a number of different types of cancer that occur in the kidney, each with a different histological type, clinical course and caused by different genetic abnormalities. Carcinogenesis can be considered as resembling an opened fan because initiated cells grow on several planes, and clinical studies of tumours suggest the edge of the fan contains many gene abnormalities: initiated cells grow in many directions and culminate in diverse clinical cancer subtypes at the periphery. The edge of the fan corresponds to pathological features (Fig. 7).

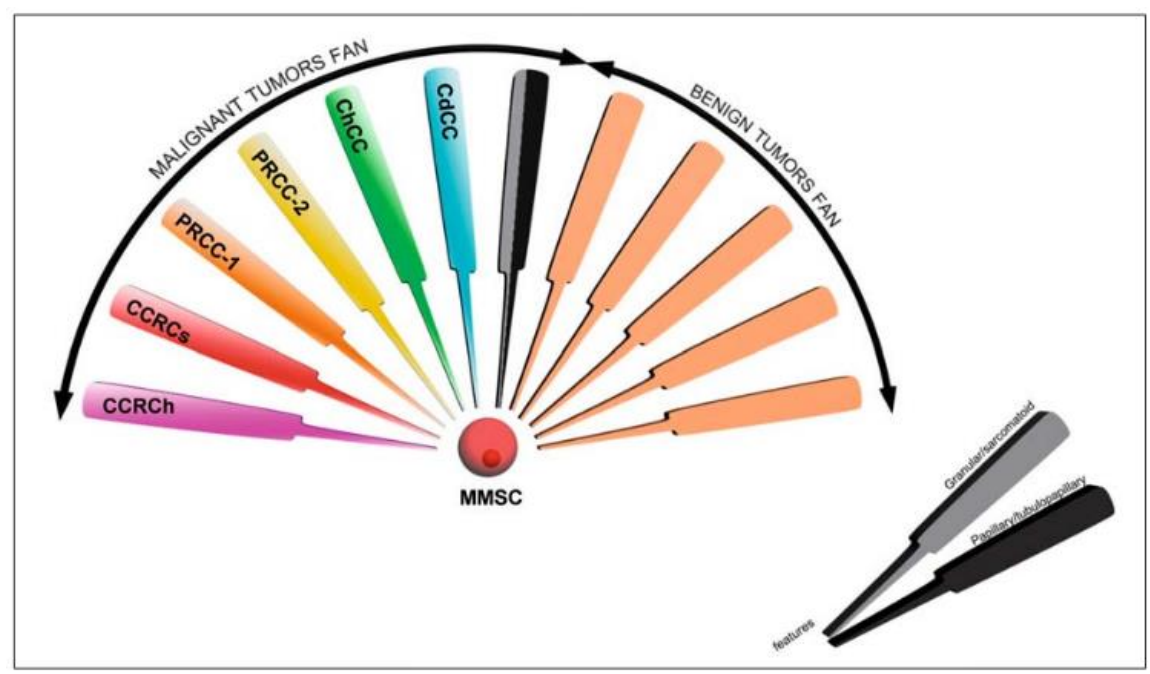

Fig. 7. Fan model of kidney epithelial carcinogenesis from stem cell niche. $\mathrm{CCRCh} / \mathrm{s}$, clear cell renal carcinoma [hereditary/sporadic]; PRCC-1/-2, papillary renal cell carcinoma [type 1/type 2]; ChCC, chromophobe cell carcinoma; Cd-CC, collecting duct cell carcinoma; MMSC, metanephric mesenchymal stem cell 
At the time the developing kidney first becomes an anatomical entity, it is made up of the metanephric mesenchyme and the invading ureteric bud. It has long been known that the cells of the ureteric bud are the precursors of the collecting duct epithelial cells; the metanephric mesenchyme contains precursors for the epithelial cells of the rest of the nephron, endothelial cells precursors and stromal cells. Given the principle that cancer must arise from a cell that has the potential to divide, and the cancer stem cell concept has arisen to describe cells that represent a minority population of a tumour, having the property of self- renewal, activated stem cells in the kidney would be the target cells for renal carcinogenesis. Inactivation of genes such as VHL, MET, FH or BHD would transform kidney tissue stem cells into hyperplastic lesions, the target for further events leading to the progression of premalignant cells to malignancy (Fig. 8).

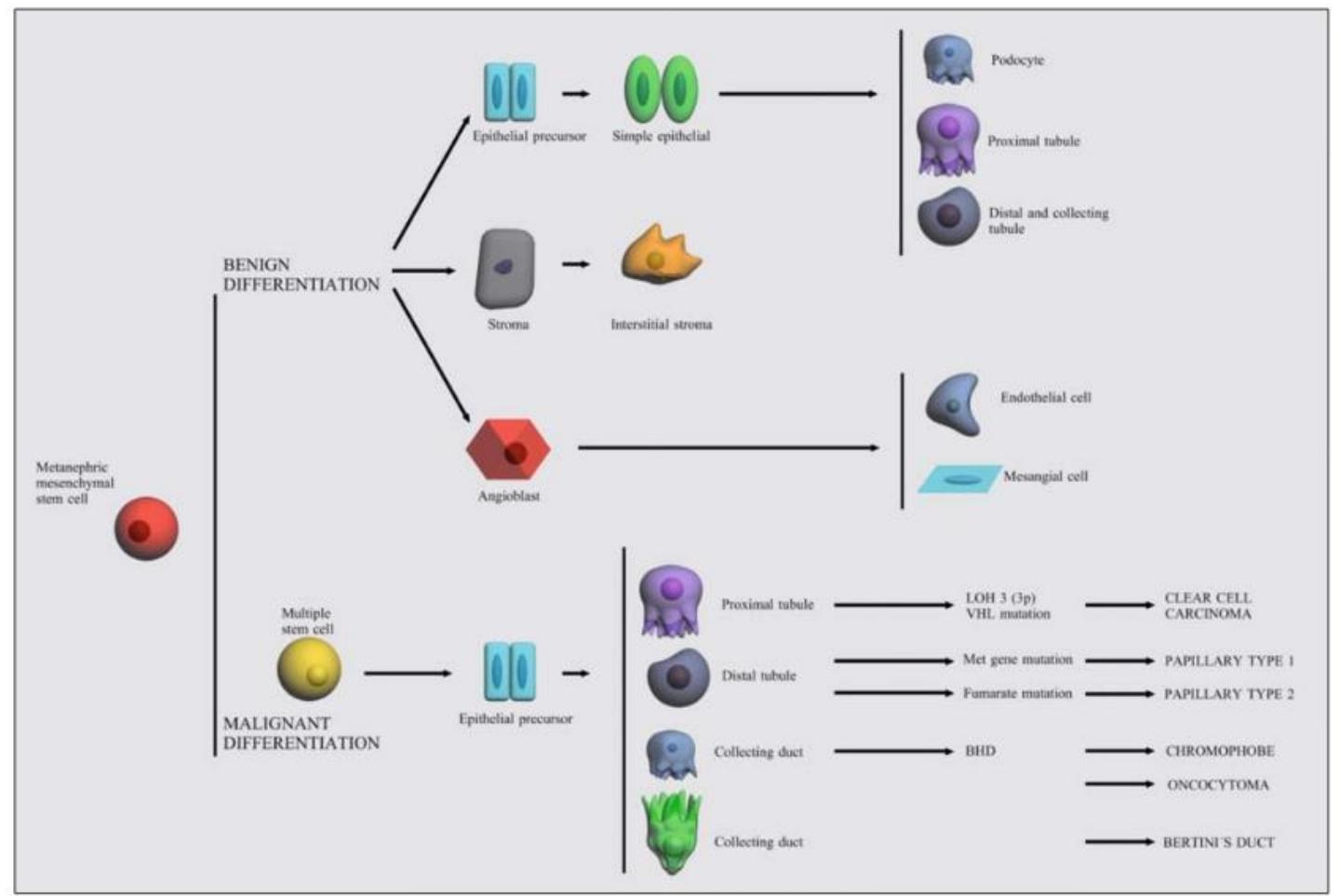

Fig. 8. Theoretical origin of different RCC types from metanephric mesenchymal stem cell through malignant differentiation induced by many mutations of specific genes

All renal cell carcinomas are, by definition, adenocarcinomas derived from renal tubular epithelial cells. Most renal cell carcinomas share ultrastructural features with nor- mal proximal tubular cells and they are believed to be derived from this region of the nephron (Fig. 9). Immuno- histochemical observations indicate that the antigenic com- position of the nephron varies in different regions [85, 86]. Antibodies to glycoproteins of various molecular weights can distinguish proximal from distal tubules and collecting ducts. Identification of these areas is not yet exact but may be helpful in determining the origin and differentiation of certain renal neoplasms [87, 88]. 


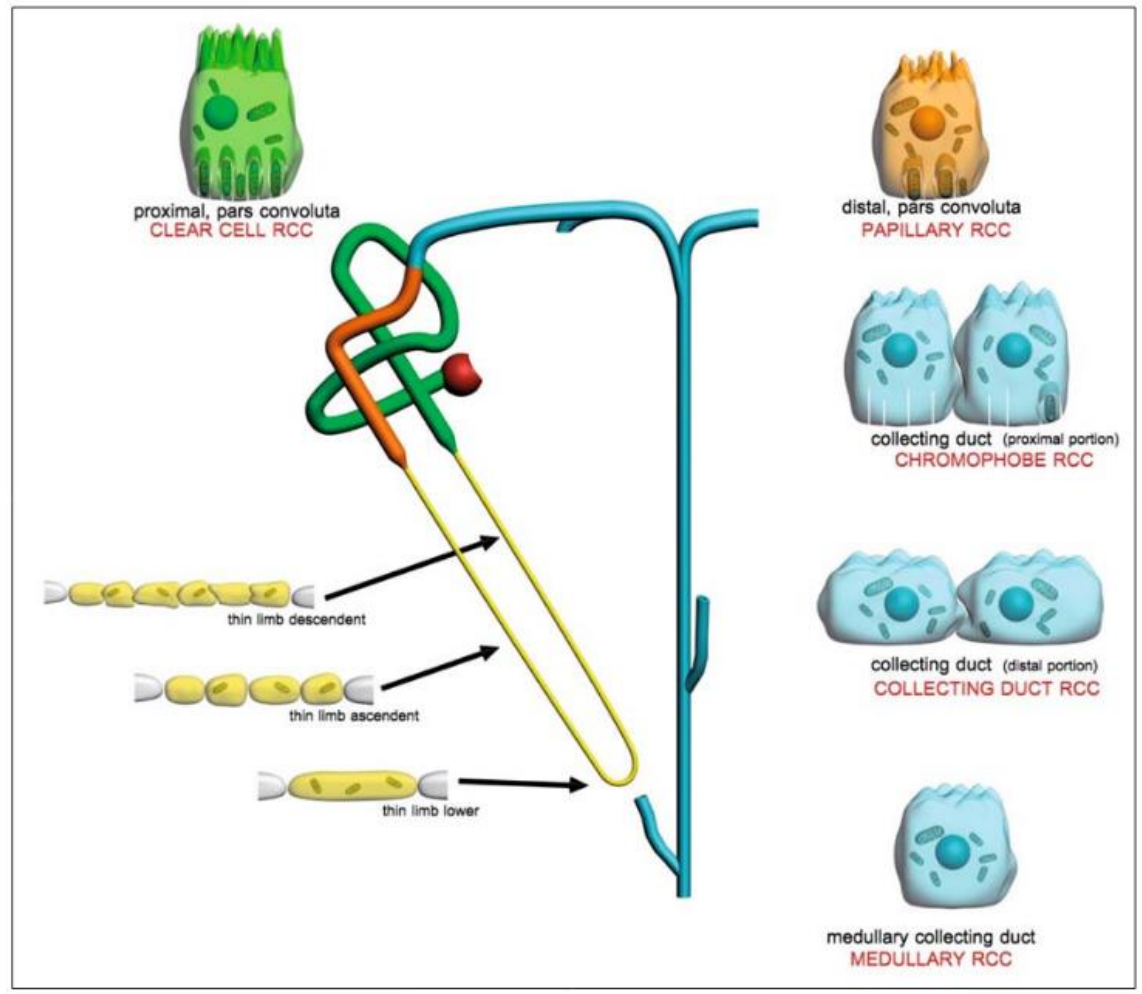

Fig. 9. Summary diagram, showing cells from the various regions of the urinary tubule (normal and tumoral)

Renal cell carcinomas were traditionally thought to arise primarily from renal tubular structures and this is probably true for most clear cell and papillary variants. Although common renal cell carcinoma and papillary renal cell carcinoma are both derived from the same part of the renal tubule and have similar antigenic phenotype, they differ in genetic changes. This might be explained by the fact that common renal cell carcinoma arises from mature renal tubular cells, whereas papillary tumours arise from embryonic origin rest; recent data suggest that the other histological subtypes are derived from the more distal components of the nephron.

\section{Clear cell carcinoma}

Clear cell carcinoma is the histopathological subtype that ac- counts for the majority of renal cell carcinomas, and occurs in both familial and sporadic forms. In both forms it is characterised by the loss of a tumour-suppressor gene, namely the VHL gene. It accounts for approximately $75 \%$ of all renal cell carcinomas. They are characterised by tumour cells with clear cytoplasm (lipid and glycogen accumulation) and an acinar growth pattern. This tumour has been a subject of intense interest and, though histogenesis remains controversial, is believed to emerge from the proximal tubule.

Immunohistochemical studies indicate that the anti- genic composition of renal cell carcinomas is variable. These neoplasms manifest determinants common to renal tubules, but evidence suggests that they develop from an uncommitted or primitive cell (stem cell) [86]. Cells tend to react with antibodies to low- and high-molecular-weight cytokeratins and vimentin (Table 4) [89, 90]. 
Table 4. Immunohistochemistry profiles of renal cell carcinomas

\begin{tabular}{|c|c|c|}
\hline $\begin{array}{l}\text { Histology } \\
\text { Architecture }\end{array}$ & Antigen markers & Reference \\
\hline Clear cell & lmw cytokeratins CK8, CK18, CK19 & $(15,16,18-23)$ \\
\hline Solid/alveolar/acinar & $\begin{array}{l}\text { AE1, Cam 5.2, Vimentin } \\
\text { hmw cytokeratins CK14, 34ßE12 }\end{array}$ & \\
\hline Papillary & $\begin{array}{l}\text { CD10, MUC1, MUC3 } \\
\text { cytokeratin CK7, vimentin } \\
\text { AE1/AE3 Cam 5.2, Callus } \\
\text { CD10, S100 }\end{array}$ & $(24,25)$ \\
\hline $\begin{array}{l}\text { Chromophobe } \\
\text { Solid/glandular }\end{array}$ & $\begin{array}{l}\text { pan cytokeratin+, vimentin - } \\
\text { EMA +, Lectins }+ \\
\text { Parvalbumin }+ \text {, CD10 }\end{array}$ & $\begin{array}{l}(18,21,22) \\
(26)\end{array}$ \\
\hline $\begin{array}{l}\text { Collecting duct } \\
\text { Tubular/tubulopapillary }\end{array}$ & $\begin{array}{l}\text { hmw keratins } 34 \text { E12, CK19 } \\
\text { lmw keratins vimentin } \\
\text { CD15, EMA, CD10- }\end{array}$ & (27) \\
\hline
\end{tabular}

\section{Papillar carcinoma}

This is the second most common histologic malignant tumour of the kidney. It accounts for approximately $5-10 \%$ of renal cell carcinomas. It is an enigmatic group that includes at least two, and possibly three, distinct types: papillary, tubular or tubulo-papillary. Some tumours have a solid growth pattern and other tumours have a striking glomeruloid appearance. Grossly, the papillary type is well circumscribed and eccentrically situated in the renal cortex. Tumours of this subtype are found in the walls of cysts. Papillary tumours often exhibit abundant lipid-laden macro phages within the interstitium of the fibrovascular cores. They tend to be multifocal and with bilateral disease. Histologic development is common in acquired cystic disease and from proximal tubule.

\section{Chromophobe cell carcinoma}

This is a distinctive histological subtype representing 3-5\% of all renal cell carcinomas. The morphological appearance includes a solid pavement or cobblestone growth pattern. It appears to be derived from the intercalated cells at the cortical portion of the collecting duct. Immunohistochemically, tumour cells react positively with antibodies to cytokeratins, epithelial membrane antigen and carbonic anhydrase C. They do not react to vimentin [91-93].

\section{Oncocytoma}

They constitute approximately $6-9 \%$ of renal cortical neo- plasms. They are characterised by tumour cells arranged in nest, cords or tubules but never exhibit a papillary growth pattern. A central, stellate scar has been considered to be characteristic of this type of tumour. It appears to be de- rived from the intercalated cells at the cortical portion of the collecting duct.

\section{Collecting duct (Bellini's duct) carcinoma}

This is a relatively rare subtype of renal cell carcinoma, ac- counting for less than $1 \%$ of all renal cell carcinomas. Collecting duct carcinoma of the kidney, including Bellini tumours, is a rare histological type of renal cell carcinoma with distinctive clinical and histopathological features. Unlike the majority of renal cell carcinoma tumours, collecting duct carcinoma originates in the distal collecting ducts [94]. Generally, the tumour is often centrally located in or near the region of the renal pelvis. Collecting ducts near the tumour often show dysplastic changes.

Collecting duct carcinomas are derived from the medulla (many are infiltrative and extension into the cortex is common). Although there are some overlapping features with papillary renal cell carcinoma, the location of medulla and the predominantly tubular configuration of the tumour 
suggest collecting duct differentiation. An origin from the collecting ducts is supported by atypical hyperplasia of the collecting duct epithelium adjacent to the neoplasm as well as immunohistochemical studies. The cells of collecting duct carcinoma react positively with antibodies to both high- and low-molecular-weight cytokeratins and epithelial membrane antigen [91-93]. Vimentin reactivity is usually negative or weakly positive. This immunohistochemistry is characteristic of distal tubular epithelium and differs from most other types of renal cell carcinoma.

\section{Conclusions}

An inherited or familial predisposition to develop kidney carcinoma represents less than $4 \%$ of all renal malignancies. However, hereditary renal cancer syndromes offer important opportunities for identification of sentinel mutations driving carcinogenesis and malignant transformation and understanding how cells acquire characteristics allowing immortalisation, evasion of apoptosis, growth in a low- oxygen environment, recruitment of growth and angiogenic factors, invasion of the basement membrane and ultimately distant spread. This knowledge is crucial in developing targeted therapeutic strategies in metastatic kidney carcinoma that is refractory to conventional chemotherapy. Moreover, for patients, the discovery of a genetic predisposition to cancer often leads to early screening of themselves and their families and thus to early detection of tumours, when treatment is most successful.

There are four well defined hereditary types of kidney cancer: VHL, HPRC type 1, BHD and hereditary HLRCC or hereditary papillary renal carcinoma type 2 (HLRCC). The gene implicated in all of them is a tumour-suppressor gene, except in HPRC type 1, in which it is the protooncogene cmet, and all these syndromes have an autosomal dominant fashion. Genetic abnormality implicated in VHL disease is the loss of chromosome 3 and the gene implicated is VHL. This tumour-suppressor gene interacts with HIF and this activates its effectors, including those involved in cell proliferation (TGF $\alpha$, VEGF, PDGF $\beta$ ) and metabolism (Glut1), which have an important role in carcinogenesis. In HPRC type 1, missense mutation in the tyrosine kinase do- main of the met gene (chromosome 7q) leads to constitutive activation of the met protein and this initiates multiple signal transduction cascades that may be carcinogenic. The FH (chromosome 1q), a Krebs cycle protein, is implicated in hereditary HLRCC. If its activity is lost, fumarate accumulation may cause HIF overexpression and carcinogenesis. Although every syndrome is associated with the gene- sis of kidney cancer, the types of renal cancers, histologic features, genes causing the defects, location, clinical course and response to therapy differ between them. In this way, almost half of people with VHL develop a kidney clear cell carcinoma which is characterised as being multiple, bilateral, arising from the proximal tubular epithelium, containing cells rich in glycogen, appearing at a young age and having a high penetrance (80-90\%). Disease "expressivity" or severity can be highly variable with other manifestations such as cerebellar and spinal haemangioblastomas, retinal angiomas, endolymphatic sac tumours, pancreatic neuroendocrine tumours, pheochromocytoma and renal, pancreatic and epididymal cysts. HPRC type 1 is usually a bilateral, multifocal carcinoma that affects proximal tubule. It appears in old people, with a low penetrance, and exhibits abundant lipid-laden macrophages. In contrast, hereditary HLRCC is associated with a solitary, extremely aggressive carcinoma which appears in $25 \%$ of the people that inherit the syndrome and may develop much earlier in life, as early as the teenage years. It tends to spread early when the tumours are small, so it causes an important mortality. Affected individuals develop extra-renal manifestations such as multiple cutaneous leiomyomatosis and uterine leiomyomas that usually occur before 35 years. Individuals affected by BHD syndrome are at risk of the development not only of kidney carcinoma but also cutaneous fibrofolliculomas, pulmonary cysts and renal spontaneous pneumothorax. This histological type initiates in Bellini's duct, in the medullary collecting tubule, and is commonly observed as an atypical hyperplasia of the adjacent collecting duct epithelium. Finally, between 15 and 30\% of people with BHD syndrome develop kidney carcinoma: 50\% oncocytic-transition carcinoma, 34\% chromophobe renal carcinoma and $5 \%$ oncocytoma, which are un- common histological types in sporadic carcinoma (less than $15 \%)$.

In conclusion, although these inherited diseases currently account for only a minority of renal cancers, the lessons learned from them (gene functions and biochemical pathways) will have profound implications for the treatment of all forms of renal cancer. 


\section{Acknowledgements}

We are grateful to Ana Carro for typing the manuscript and Julio Aparicio \& Eva Senín for artistic design. Guadalupe Aparicio Gallego is supported by Fundación Juan Canalejo Marítimo Oza from A Coruña (Spain) and Silvia Díaz Prado is a beneficiary of an Isidro Parga Pondal contract by the "Xunta de Galicia" (Spain).

\section{References}

1. Knudson AG (1971) Mutation and cancer: statistical study of retinoblastoma. Proc Natl Acad Sci USA 69:820-823

2. Knudson AG, Strong LC (1976) Mutation and cancer: a model for Wilms' tumor of the kidney. J Natl Cancer Inst 48:313-324

3. Zimmer M, Iliopoulos O (2003) Molecular genetics of kidney cancer. Cancer Treat Res 116:3-27

4. Pavlovich CP, Schmidt LS (2004) Searching for the hereditary causes of renal-cell carcinoma. Nat Rev Cancer 4:381-393

5. Al-Awqati Q, Oliver JA (2002) Stem cells in the kidney. Kidney Int 61:387-395

6. Savage COS (1994) The biology of the glomerulus: endothelial cells. Kidney Int 45:314319

7. Johnson RJ, Floege J, Yoshimura A et al (1992) The activated mesangial cell: a glomerular "myofibroblast". J Am Soc Nephrol 2[Suppl 10]: S190-19

8. El Nahas AM, Muchaneta-Kubara EC, Essawy M, Soylemezoglu O (1997) Renal fibrosis: insights into pathogenesis and treatment. Int J Biochem Cell Biol 29:55-62

9. Lidhal P, Hellstrom M, Kalen M et al (1998) Paracrine PDGF-B/PDGF-R beta signalling controls mesangial development in kidney glomeruli. Development 125:3313-3322

10. Naruse K, Fujieda M, Miyazaki E et al (1999) CD34 expression as a novel marker of transformed mesangial cells in biopsied glomerular diseases. J Pathol 189:105-111

11. Simmons PJ, Torok-Storb B (1991) CD34 expression by stromal precursors in normal human adult bone marrow. Blood 78:2848-2853

12. Ng YY, Fan JM, Mu W et al (1999) Glomerular epithelial-myofibroblast transdifferentiation in the evolution of glomerular crescent formation. Nephrol Dial Transpl 14:2860-2872

13. Jernigan SJ, Eddy AA (2000) Experimental insights into the mechanisms of tubulointerstitial scarring. In: El Nahas AM, Anderson S, Harris KPG (eds) Mechanisms and management of progressive renal failure. Oxford University Press, London, pp 104145

14. Fan JM, Ng YY, Hill PA et al (1999) Transforming growth factor-beta regulates tubular epithelial myofibroblast transdifferentiation in vitro. Kidney Int 56:1455-1467

15. Zeisberg M, Strutz F, Muller GA (2000) Renal fibrosis: an update. Curr Opin Nephrol Hypert 10: 315-320

16. Lineham WM, Lerman MI, Zbar B (1995) Identification of the von Hippel-Lindau (VHL) gene: its role in renal cancer. JAMA 273:564-570

17. Glenn GM, Choyke PL, Zbar B, Lineham WM (1990) Von Hippel-Lindau disease: clinical review and molecular genetics. In: Anderson E (ed.) Problems in urologic surgery: benign and malignant tumors of the kidney. J.B. Lippincott, Philadelphia, pp 312-330

18. Poston CD, Jaffe GS, Lubensky IA et al (1995) Characterization of the renal pathology of a familial form of renal cell carcinoma associated with von Hippel-Lindau disease: clinical and molecular genetics implications. J Urol 153:22-26

19. Cohen AJ, Li FP, Berg S et al (1979) Hereditary renal-cell carcinoma associated with a chromosomal translocation. New Engl J Med 301:592-595

20. Kovacs G, Brusa P, De Riese W (1989) Tissuespecific expression of a constitutional 3;6 translocation: development of multiple bilateral renal-cell carcinomas. Int J Cancer 43:422-427

21. Zbar B, Tory K, Marine M et al (1994) Hereditary papillary renal cell carcinoma. J Urol 151:561-566

22. Zbar B, Glenn G, Lubensky I et al (1995) Hereditary papillary renal cell carcinoma: clinical studies in 10 families. J Urol 153:907-912

23. Weirich G, Glenn G, Junker K et al (1998) Familial renal oncocytoma: clinicopathological study of 5 families. J Urol 160:335-340

24. Tory K, Brauch H, Linehan M et al (1989) Specific genetic change in tumors associated with von Hippel-Lindau disease. J Natl Cancer Inst 81: 1097-1101

25. Shi G, Cannizzaro LA (1996) Mapping of 29 YAC clones and identification of 3 YACs spanning the translocation $\mathrm{t}(3 ; 8)(\mathrm{p} 14.2 ; \mathrm{q} 24.1)$ breakpoint at $8 \mathrm{q} 24.1$ in hereditary renal cell carcinoma. Cytogenet Cell Genet 75:180-185 
26. Bodmer D, Eleveld MJ, Ligtenberg MJ et al (1998) An alternative route for multistep tumorigenesis in a novel case of hereditary renal cell carcinoma and at $\mathrm{t}(2 ; 3)(\mathrm{q} 35 ; \mathrm{q} 21)$ chromosomal translocation. Am J Hum Genet 62:1475-1483

27. Wang N, Perkins KL (1984) Involvement of band 3p14 in $\mathrm{t}(3 ; 8)$ hereditary renal carcinoma. Cancer Genet Cytogenet 11:479-481

28. Schmidt L, Duh FM, Chen F et al (1997) Germline and somatic mutations in the tyrosine kinase domain of the MET proto-oncogene in papillary renal carcinomas. Nat Genet 16:68-73

29. Schmidt LS, Warren MB, Nickerson ML et al (2001) Birt Hogg Dubé syndrome, a genodermatosis associated with spontaneous pneumothorax and kidney neoplasia, maps to chromosome 17p11.2. Am J Hum Genet 69:876-882

30. Nickerson ML, Warrem MR, Toro JR et al (2002) Mutations in a novel gene lead to kidney tumors, lung wall defects, and benign tumors of the hair follicle in patients with Birt-Hogg-Dubé syndrome. Cancer Cell 2:157-164

31. Kiuru M, Launonen V, Hietala M et al (2001) Familial cutaneous leiomyomatosis is a two-hit condition associated with renal cell cancer of characteristic histopathology. Am J Pathol 159:825-829

32. Isaacs JT, Jung YJ, Mole DR et al (2005) HIF overexpression correlates with biallelic loss of fumarate hydratase in renal cancer: novel role of fumarate in regulation of HIF stability. Cancer Cell 8:143-153

33. Couch V, Lindor NM, Karnes PS, Michels VV (2000) Von Hippel-Lindau disease. Mayo Clin Proc 75:265-272

34. Maher ER, Iselius L, Yater JR et al (1991) Von Hippel-Lindau disease: a genetic study. J Med Genet 28:443-447

35. Lenehan WM, Zbar B, Klausner RD (2001) Renal carcinoma. In: Scriver CR, Beaudet AL, Sly WS, Valle D (eds) Metabolic and molecular basis of inherited disease. McGrawHill, New York

36. Tory K, Braauch H, Linehan WM et al (1989) Specific genetic change in tumors associated with von Hippel-Lindau disease. J Natl Cancer Inst 81:1097-1101

37. Latif F, Tory K, Gnarra J et al (1993) Identification of the von Hippel-Lindau disease tumor suppressor gene. Science 260:1317-1320

38. Iliopoulos O, Eng C (2000) Genetics and clinical aspects of familial renal neoplasms. Semin Oncol 27:138-149

39. Seizinger BR, Rouleau GA, Ozellius LJ et al (1988) Von Hippel-Lindau disease maps to the region of chromosome 3 associated with renal cell carcinoma. Nature 332:268-269

40. Lubensky IA, Gnarra JR, Bertheau P et al (1996) Allelic deletions of the VHL gene detected in multiple microscopic clear cell renal lesions in von Hippel-Lindau disase patients. Am J Pathol 149:2089-2094

41. Hosoe S, Brauch H, Latif F et al (1990) Localization of the von Hippel-Lindau disease gene to a small region of chromosome 3. Genomics 8:634-640

42. Richars FM, Maher ER, Latif F et al (1993) Detailed genetic mapping of the von HippelLindau disease tumor suppressor gene. J Med Genet 30: 104-107

43. Chen F, Kishida T, Yao M et al (1995) Mutations in the von Hippel-Lindau disease tumor suppressor gene: correlations with phenotype. Hum Mutat 5:66-75

44. Abar B, Kishida T, Chen F et al (1996) Germline mutations in the von Hippel-Lindau disease (VHL) gene in families from North America, Europe and Japan. Hum Mutat $8: 349-357$

45. Walther MM, Enquist EG, Jennings SB et al (1999) Molecular genetics of renal cel carcinoma. In Vogelzang NJ, Scardino PT, Shipley WU et al (eds) Comprehensive textbook of genitourinary oncology. Williams/Wilkins, Baltimore, pp 116-128

46. Bottaro DP, Rubin JS, Faletto DL et al (1991) Identification of the hepatocyte growth factor receptor as the c-met proto-oncogene product. Science 251:802-804

47. Huang Z, Park WS, Pack S et al (1998) Trisomy 7-harboring nonrandom duplication of the mutant MET allele in hereditary papillary renal carcinomas. Nat Genet 20:66-69

48. Kovacs G, Ishikawa I (1993) High incidence of papillary renal cell tumours in patients on chronic haemodialysis. Histopathology 22:135-139

49. Zambrano NR, Lubensky IA, Merino MJ et al (1999) Histopathology and molecular genetics of renal tumors: toward unification of a classification system. J Urol 162:12461258

50. Kovacs G, Tory K, Kovacs A (1994) Development of papillary renal cell tumours is associated with a loss of Y-chromosome-specific DNA sequences. J Pathol 173:39-44

51. Thrash-Bingham CA, Salazar H, Freed JJ et al (1995) Genomic alterations and instabilities in renal cell carcinomas and their relationship to tumor pathology. Cancer Res 55:6189-6195

52. Tonk V, Wilson KS, Timmons CF et al (1995) Renal carcinoma with translocation (X;1): further evidence for cytogenetically defined subtype. Cancer Genet Cytogenet 81:72-75 
53. Kovacs G, Szucs S, Deriese W, Baumgartel H (1978) Specific chromosomal aberration in human renal cell carcinoma. Int J Cancer 40:171-178

54. Zbar B, Glenn G, Lubensky I et al (1995) Hereditary papillary renal cell carcinoma: clinical studies in 10 families. J Urol 153:907-912

55. Duh FM, Scherer SW, Tsui LC et al (1997) Gene structure of the human MET protooncogene. Oncogene 15:1583-1586

56. Choyke PL, Glenn GM, Walther MM et al (2003) Hereditary renal cancers. Radiology 226:33-46

57. Pavlovich CP, Walther MM, Eyler RA et al (2002) Renal tumors in the Birt-Hogg-Dube syndrome. Am J Surg Pathol 26:1542-1552

58. Polascik TJ, Bostwick DG, Cairns P (2002) Molecular genetics and histopathologic features of adult distal nephron tumors. Urology 60:941-946

59. Birt AR, Hogg GR, Dube WJ (1977) Hereditary multiple fibrofolliculomas with trichodiscomas and acrochordons. Arch Dermatol 113:1674-1677

60. Pan CC, Chen PC, Chiang H (2004) Overexpression of KIT (CD117) in chromophobe renal cell carcinoma and renal oncocytoma. Am J Clin Pathol 121:878-883

61. Petit A, Castillo M, Santos M et al (2004) KIT expression in chromophobe renal cell carcinoma: comparative immunohistochemical analysis of KIT expression in different renal cell neoplasms. Am J Surg Pathol 28:676-678

62. Antonelli A, Portesi E, Cozzot A et al (2003) The collecting duct carcinoma of the kidney: a cytogenetical study. Eur Urol 43:680-685

63. Foster K, Crossey PA, Cairns P et al (1994) Molecular genetic investigation of sporadic renal cell carcinoma: analysis of allele loss on chromosomes 3p,5q,11p,17 and 22. $\mathrm{Br} \mathrm{J}$ Cancer 69:230-234

64. Lubinski J, Hadaczek P, Podolski J et al (1994) Common regions of deletion in chromosome regions 3p12 and 3p14.2 in primary clear cell renal carcinomas. Cancer Res $54: 3710-3713$

65. Knebelmann B, Ananth S, Cohen HT, Sukhatme VP (1998) Transforming growth factor alpha is a target for the von Hippel-Lindau tumor suppressor gene. Cancer Res 58:226231

66. Gomella LG, Sargent ER, Wade TP et al (1989) Expression of transforming growth factor alpha in normal human adult kidney and enhanced expression of transforming growth factors alpha and beta 1 in renal cell carcinoma. Cancer Res 49:6972-6975

67. Kinouchi T, Saiki S, Naoe T et al (1989) Correlation of c-myc expression with nuclear pleomorphism in human renal cell carcinoma. Cancer Res 9:3627-3630

68. Kenck C, Bugert P, Wilhelm M, Kovacs G (1997) Duplication of an approximately 1.5 Mb DNA segment at chromosome 5q22 indicates the locus of a new tumour gene in nonpapillary renal cell carcinomas. Oncogene 14:1093-1098

69. Kovacs G (1993) Molecular cytogenetics of renal tumors. Adv Cancer Res 62:89-124

70. Presti JC, Moch H, Reuter VE et al (1996) Renal cell carcinoma genetic analysis by comparative ge nomic hybridation and restriction fragment length polymorphism analysis. J Urol 156:281-285

71. Gannon JV, Greaves R, Iggo R, Lane DP (1990) Activating mutations in p53 produce a common conformational effect. A monoclonal antibody specific for the mutant form. EMBO J 9:1595-1602

72. Levine AJ, Momand J, Finlay CA (1991) The p53 tumour suppressor gene. Nature 351:453-456

73. Oda H, Nakatsuru Y, Ishikawa T (1995) Mutations of the p53 gene and p53 protein overexpression are associated with sarcomatoid transformation in renal cell carcinomas. Cancer Res 55:658-662

74. Hofmockel G, Wittmann A, Dammrich J, Basukas ID (1996) Expression of p53 and bcl-2 in primary locally confined renal cell carcinomas: no evidence for prognostic significance. Anticancer Res 16:3807-3811

75. Dijkhuizen T, Van Den Berg E, Van Den Berg A et al (1997) Genetics as a diagnostic tool in sarcomatoid renal cell cancer. Int J Cancer 72:265-269

76. Teysier JR, Ferre D (1990) Chromosomal changes in renal cell carcinoma. No evidence for correlation with clinical stage. Cancer Genet Cytogenet 45:197-205

77. Presti JC, Reuter VE, Cordon-Cardo C et al (1993) Allelic deletions in renal tumors: his to patho logical correlations. Cancer Res 53:5780-5783

78. Wu SQ, Hafez GR, Xing W et al (1996) The correlation between the loss of chromosome $14 \mathrm{q}$ with histologic tumor grade, pathologic stage, and outcome of patients with nonpapillary renal cell carcinoma. Cancer 77:1154-1160

79. Schullerus D, Herbers J, Chudek J et al (1997) Loss of heterozygosity at chromosomes $8 p, 9 p$, and $14 q$ is associated with stage and grade of nonpapillary renal cell carcinomas. $\mathrm{J}$ Pathol 183:151-155

80. Pisters LL, el-Naggar AK, Luo W et al (1997) C-met proto-oncogen expression in benign and malignant human renal tissues. J Urol 158:724-728 
81. Nakopoulou L, Vouriakou C, Papaliodi E et al (1997) Immunodetection of c-metoncogene's protein product in renal cell neoplasia. Path Res Pract 193:299-304

82. Natali PG, Prat M, Nicotra MR et al (1996) Over-expression of the met-HGF receptor in renal cell carcinomas. Int J Cancer 69:212-217

83. Sargent ER, Gomella LG, Belldegrun A et al (1989) Epidermal growth factor receptor gene expression in normal human kidney and renal cell carcinoma. J Urol 142:1364-1368

84. Weidner U, Peter S, Strohmeyer T et al (1990) Inverse relationship of epidermal growth factor receptor and HER2/neu gene expression in human renal cell carcinoma. Cancer Res 50:4504-4509

85. Bander NH, Cordon-Cardo C, Finstad CL et al (1985) Immunohistologic dissection of the human kidney using monoclonal antibodies. J Urol 133: 502-505

86. Cohen C, McCue PA, Derose PB (1988). Histogenesis of renal cell carcinoma and oncocytoma. An immunohistochemical study. Cancer 62:1946-1951

87. Hennigar RA, Spicer SA, Sens DA et al (1986) Histochemical evidence for tubule segmentations in a case of Wilms' tumor. Am J Clin Pathol 85: 724-731

88. Medeiros LJ, Michie SA, Johnson DE et al (1988) An immunoperoxidase study of renal cell carcinomas: correlations with nuclear grade, cell type and histologic pattern. Hum Pathol 19:980-987

89. Wick MR, Cherwitz DL, Manivel JC, Sibley R (1999) Immunohistochemical findings in tumors of the kidney. In Eble JN (ed.) Tumors and tumor-like conditions of the kidneys and ureters. Churchill Livingstone, New York, pp 207-247

90. Yoshida SO, Iman A, Olson CA, Taylar CR (1986) Proximal renal tubular surface membrane antigens identified in primary and metastatic renal cell carcinomas. Arch Pathol Lab Med 110:825-832

91. Fleming S, Symes CE (1987) The distribution of cytokeratin antigens in the kidney and in renal tumors. Histopathology 11:157-170

92. Mc Gregor DK, Khurana KH, Cao C et al (2001) Diagnosing primary and metastatic renal cell carcinoma: the use of the monoclonal antibody. Renal Cell Carcinoma Marker. Am J Surg Pathol 25: 1485-1492

93. Pitz S, Moll R, Storkel S, Thoenes W (1987) Expression of intermediate filament proteins in subtypes of renal cell carcinomas and in renal oncocytoma. Distinction of two classes of renal cell tumors. Lab Invest 56:642-653

94. Chu PG, Weiss LM (2001) Cytokeratin 14 immunoreactivity distinguishes oncocytic tumour from its renal mimics: an immunohistochemical study of 63 cases. Histopathology $39: 455-462$ 